\title{
ECLETICA
}

www.scielo.br/eq

www.ecletica.iq.unesp.br

Volume 33, número 1, 2008

\section{Preparation of nano-MgO using ultrasonic method and its characteristics}

\author{
Zhen-Xing Tang*, Lu-E Shi \\ College of Pharmaceutical Science, Zhejiang University of Technology, 310014, Hangzhou, Zhejiang, P R China \\ *tangzhenxing@126.com
}

\begin{abstract}
MgO}$ is an important inorganic material, which can be used in many aspects, such as catalyst, toxic-waste remediation agent, adsorbent, and others. In order to make use of $\mathrm{MgO}$, nano- $\mathrm{MgO}$ was prepared by ultrasonic method using $\mathrm{Mg}\left(\mathrm{CH}_{3} \mathrm{COO}\right)_{2} \cdot 2 \mathrm{H}_{2} \mathrm{O}$ as precursor, $\mathrm{NaOH}$ aqueous solution as precipitant in this paper. Effect factors on $\mathrm{MgO}$ nano-particle size were investigated. Characteristics of samples were measured by TGA, XRD, TEM, and others techniques. The results showed that the size of nano- $\mathrm{MgO}$ about $4 \mathrm{~nm}$ could be obtained under the following conditions (ultrasonic time 20 min, ultrasonic power $250 \mathrm{~W}$, titration rate of $\mathrm{NaOH} 0.25 \mathrm{~mL} / \mathrm{min}, \mathrm{NaOH}$ concentration $0.48 \mathrm{~mol} / \mathrm{L}$, calcinations temperature $410{ }^{\circ} \mathrm{C}$, calcination time $1.5 \mathrm{~h}$, heating rate of calcination $5{ }^{\circ} \mathrm{C} / \mathrm{min}$ ). It was a very simple and effective method to prepare nano-MgO.
\end{abstract}

Keyword: $\mathrm{MgO}$; nano-particle size; ultrasonic method.

\section{Introduction}

The alteration of the bulk electronic structure of nanosized materials causes change in the total energy of the system, so that, ignoring entropy considerations, it will thermodynamically stabilize the reduced scale system relative to that of normal bulk crystals. Such alterations may change the most energetically stable form of a particular material, as when small nanoparticles or nanodimensional layers adopt a crystal structure different from that of the normal bulk material. The surface area to volume ratio $(\mathrm{S} / \mathrm{V})$ and the specific surface area of a system are inversely proportional to particle size. Both $\mathrm{S} / \mathrm{V}$ and specific surface area increase drastically for particles less than $100 \mathrm{~nm}$ in diameter. Reduction of the system size may change the chemical reactivity and physical properties such as electrical, thermal, optical and magnetic characteristics $[1,2]$.

Due to their different physical and chemical properties, nano-structured materials have received increasing attention in various fields of science and technology [3-5]. A variety of physicochemical methods, including metal evaporation [6], spray pyrolysis [7], sol-gel [8], hydrothermal synthesis [9] and electrochemical methods [10], have been used to produce nanometer-sized materials.

Recently, the sonochemical methods have been shown to be very promising in the preparation of a variety of materials with nanometer dimensions, including nanochalcogenides [11, 12], metallic nanoparticles [13, 14] and nanosized metal oxides $[15,16]$. These materials possess improved magnetic properties [17], energy storage capacities [18-20] and photocatalytic [21] and catalytic properties [22]. 
$\mathrm{MgO}$ is an exceptionally important material, which used in catalyst, toxic-waste remediation agent, or as an additive in refractory, paint as well as for fundamental and application studies [23]. Ultra-fine metal oxide particles can be used as bactericide, adsorbent, and catalyst. $\mathrm{MgO}$ in particular has shown great promising application as a destructive adsorbent for toxic chemical agent [24]. This paper presented an ultrasonic route for preparing $\mathrm{MgO}$ nano-particles. Effect factors on $\mathrm{MgO}$ nano-particle size were investigated. It is a good method to prepare nano-MgO.

\section{Experimental details}

\section{Materials}

$\mathrm{Mg} \quad\left(\mathrm{CH}_{3} \mathrm{COO}\right)_{2} . \quad 2 \mathrm{H}_{2} \mathrm{O} \quad$ (Mallinkrodt baker inc, ACS); Sodium hydroxide (BMD chemicals inc, ACS); Other reagents were gotten from local supplies.

\section{Preparation of $\mathrm{MgO}$ nano-particles}

$\mathrm{Mg}\left(\mathrm{CH}_{3} \mathrm{COO}\right)_{2} .2 \mathrm{H}_{2} \mathrm{O}$ was dissolved in ethanol solution. Then $\mathrm{NaOH}$ solution was titrated into the above solution under ultrasound. After it being sonicated about $20 \mathrm{~min}$, the transparent solution could be gotten. All organic substances were removed by reduced distillation. Then it was dried at $50{ }^{\circ} \mathrm{C}$ for about $1.5 \mathrm{~h}$ under vacuum condition. Finally, $\mathrm{MgO}$ nano-particles with different sizes could be obtained through calcining.

\section{Analysis Methods}

TGA measurements were carried out using Netzsch STA 409 Apparatus; The size and Particle size distribution in ethanol was recorded on Submicron Particle Sizer (NICOMP 370, USA); TEM photomicrographs were obtained using Philips 201 Transmission Electron Microscope. The pictures were taken at $80 \mathrm{kV}$. The deposit was scraped away from the support and then transferred to the Fromvar $1595 \mathrm{E}$ (Merck) membrane coated $\mathrm{Cu}$ grid (mesh 400); Rigaku Geiferflex X-ray diffractometer with $\mathrm{Ni}$-filtered $\mathrm{Cu}$ Ka radiation $(40 \mathrm{kV}, 30 \mathrm{~mA}$ ) was used to determine the crystallinity and phase of the samples.

\section{Results and Discussion}

TGA study of the intermediate

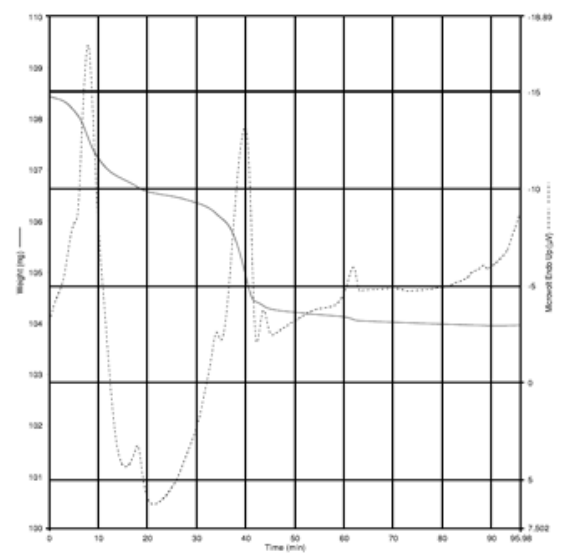

Figure 1. TGA of $\mathrm{Mg}(\mathrm{OH})_{2}$ Conditions: hold for 1 min at $50{ }^{\circ} \mathrm{C}$; heat from $50{ }^{\circ} \mathrm{C}$ to $1000{ }^{\circ} \mathrm{C}$ at the rate $10{ }^{\circ} \mathrm{C} / \mathrm{min}$; hold for $1 \mathrm{~h}$ at $1000{ }^{\circ} \mathrm{C}$.

Decomposition temperatures are different for different intermediates. Decomposition temperature of the same intermediates is relative to the precursors [25-27]. For example, $\mathrm{Mg}(\mathrm{OH})_{2}$ can be obtained from the precursor $\mathrm{MgSO}_{4} \cdot 7 \mathrm{H}_{2} \mathrm{O}$, $\mathrm{Mg}\left(\mathrm{CH}_{3} \mathrm{CO}_{3}\right)_{2} \cdot 4 \mathrm{H}_{2} \mathrm{O}$ and $\mathrm{Mg}\left(\mathrm{NO}_{3}\right)_{2} \cdot 6 \mathrm{H}_{2} \mathrm{O}$. Decomposition temperature of $\mathrm{Mg}(\mathrm{OH})_{2}$ is about $920{ }^{\circ} \mathrm{C}, 310{ }^{\circ} \mathrm{C}, 390{ }^{\circ} \mathrm{C}$, respectively. The last two intermediates can be decomposed into $\mathrm{MgO}$ below $400{ }^{\circ} \mathrm{C}$. But, for the first intermediate, $\mathrm{MgO}$ can be obtained when the temperature is more than $900{ }^{\circ} \mathrm{C}$.

To further characterize the intermediate, TGA profiles was measured. According to TGA of the intermediate (Fig. 1), we could know the sample was $\mathrm{MgO} . \mathrm{MgO}$ nano-particles could be gotten at $410{ }^{\circ} \mathrm{C}$ through calcining of the intermediate in our paper. The calcinations temperature was lower than the results reported by $\mathrm{Wu}$ Shan [27]. Ethanol mediated magnesium intermediate showed a weight loss in two steps at 80 and $410{ }^{\circ} \mathrm{C}$, respectively. The corresponding DTA showed endothermic peaks at $80{ }^{\circ} \mathrm{C}$ was due to removal of ethanol from magnesium intermediate. The DTA peak at $410{ }^{\circ} \mathrm{C}$ was due to the decomposition of magnesium intermediate to form $\mathrm{MgO}$. Using TGA data, magnesium intermediate obtained was decomposed at $410{ }^{\circ} \mathrm{C}$. 


\section{Effect of factors on $\mathrm{MgO}$ nano-particle size}

\section{Effect of $\mathrm{NaOH}$ concentration on the size}

For precipitant method, the ratio (the nucleant rate: the crystal growth rate) is increased with the increasing of reactant concentration when reactant concentration is at certain concentration scope. Nano-particle size turns smaller along with the increasing of reactant concentration at this concentration scope too. When the reactant concentration oversteps this certain concentration, although the nucleant rate is very fast, it is easy to get big size nano-particle due to high particle density, high impact probability and the serious aggregation of particles. So with the increasing of reactant concentration, the trend of particle size is decreased first, and then increased [28]. When the ultrasound is introduced into this method, the nucleant rate is further increased [29-32]. Vast amount of micro air bubble is formed due to ultrasonic cavitate. These micro air bubbles can disturb the ordered crystal sequence. It will affect the crystal growing further. Shock wave with high pressure and micro-emission fluid produced by ultrasonic cavitate, can bring comminution and emulsification, stir, and others mechanical influences. It can effectively prevent the crystal growth and aggregation. This influence makes the nucleant rate far higher than precipitant method's. The small size nano-particle with uniform size distribution is easy to be obtained [30-33]. However, this influence is relative to super-saturation solution. If the super-saturation degree is low, it can be effective. If the super-saturation degree is high, the crystal growth rate is too

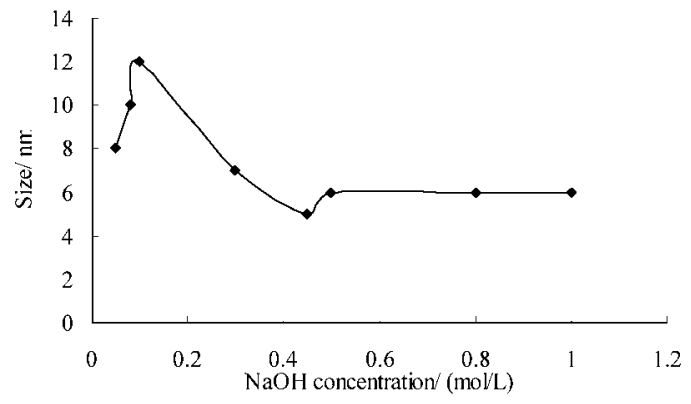

Figure 2. Effect of $\mathrm{NaOH}$ concentration on the size. Conditions: Ultrasonic time: $20 \mathrm{~min}$; Ultrasonic power: $250 \mathrm{~W}$; titration rate of $\mathrm{NaOH}$ : $0.25 \mathrm{~mL} / \mathrm{min}$; Calcinations temperature: $410{ }^{\circ} \mathrm{C}$; Heating rate of calcinations: $5^{\circ} \mathrm{C} / \mathrm{min}$; Calcinations time: $1.5 \mathrm{~h}$. fast. The ultrasound has little effect on the crystal growth rate. But the mechanical influence produced by ultrasonic cavitate can prevent the crystal growing. When super-saturation is increased further, both have little influence on the crystal growth rate. This phenomenon is the same with general precipitant method [34]. From Fig.2, we could know the smallest size was about $5 \mathrm{~nm}$ when $\mathrm{NaOH}$ concentration was $0.48 \mathrm{~mol} / \mathrm{L}$.

\section{Effect of titration rate of $\mathrm{NaOH}$ on the size}

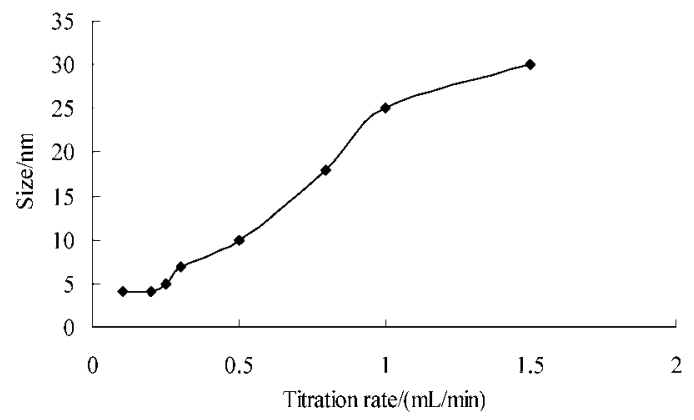

Figure 3. Effect of titration rate on the size. Conditions: Ultrasonic time: $20 \mathrm{~min}$; Ultrasonic power: $250 \mathrm{~W}$; $\mathrm{NaOH}$ concentration: $0.48 \mathrm{~mol} / \mathrm{L}$; Calcinations temperature: $410{ }^{\circ} \mathrm{C}$; Heating rate of calcinations: $5^{\circ} \mathrm{C} / \mathrm{min}$; Calcinations time: $1.5 \mathrm{~h}$.

From Figure 3, the size was similar when titration rate of $\mathrm{NaOH}$ was below $0.25 \mathrm{~mL} / \mathrm{min}$. With the decrease of titration rate, the size of nanoparticles became smaller. The concentration of nano-particles was low. And vast amount of crystal were formed due to ultrasonic cavitate. At the same time, the mechanical influence produced by ultrasonic cavitate such as comminution, emulsification, stir, and others, was increased with prolonging of titration rate. Thus, it could prevent the nanoparticle growing and aggregating.

\section{Effect of ultrasonic time on the size}

The mechanical influence produced by ultrasonic cavitate such as comminution, emulsification, stir, and others, could prevent the crystal growth and aggregation. But when the ultrasonic time was too long, shock wave with high pressure, micro-emission fluid and "Brown phenomenon" of nano-particle itself could make nano-particles aggregated. The longer the ultrasonic time was, the more serious the aggregation was. From Fig.4, the optimal ultrasonic time was about $20 \mathrm{~min}$. 


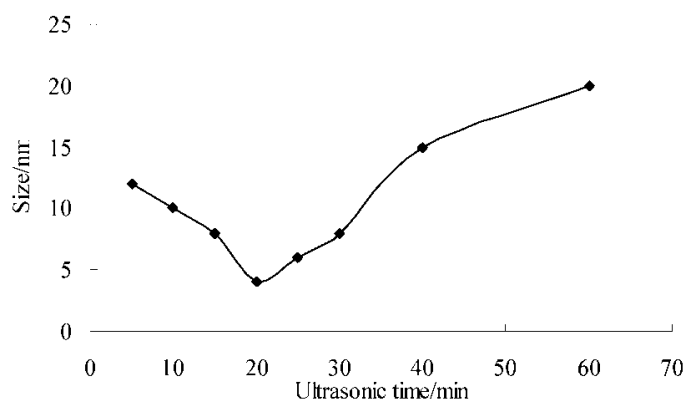

Figure 4. Effect of ultrasonic time on the size. Conditions: Titration rate of $\mathrm{NaOH}: 0.25 \mathrm{~mL} / \mathrm{min}$; Ultrasonic power: $250 \mathrm{~W}$; $\mathrm{NaOH}$ concentration: 0.48 $\mathrm{mol} / \mathrm{L}$; Calcinations temperature: $410{ }^{\circ} \mathrm{C}$; Heating rate of calcinations: $5^{\circ} \mathrm{C} / \mathrm{min}$; Calcinations time: $1.5 \mathrm{~h}$.

\section{Effect of ultrasonic power on the size}

From Figure 5, we could know when ultrasonic power was low (about $250 \mathrm{w}$ ), the influence on the size was little. With the increasing of power, the temperature of the system was increased. The adverse effect of ultrasonic power on nano-particles nucleation, growth and formation appeared. The big size nano-particle was easy to obtain. So the optimized ultrasonic power was $250 \mathrm{~W}$.

\section{Effect of calcinations temperature and calcina-} tions time on the size

Calcinations techniques are crucial to get nano-MgO with small size and high surface area. When calcinations temperature is low, the intermediate might not be decomposed completely. It must prolong calcinations time to make the intermediate

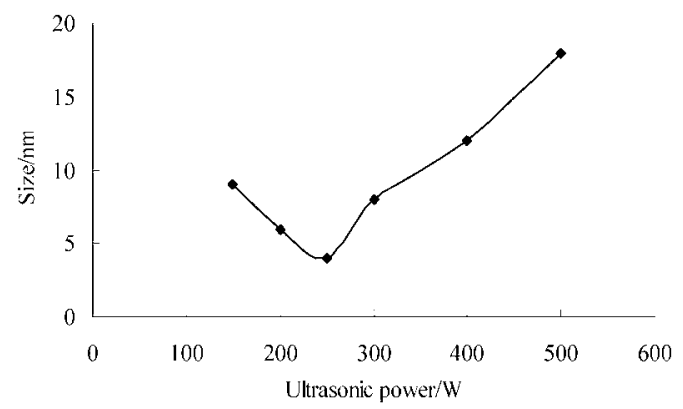

Figure 5. Effect of ultrasonic power on the size. Conditions: Titration rate of $\mathrm{NaOH}: 0.25 \mathrm{~mL} / \mathrm{min}$; Ultrasonic time: $20 \mathrm{~min}$; $\mathrm{NaOH}$ concentration: 0.48 $\mathrm{mol} / \mathrm{L}$; Calcinations temperature: $400{ }^{\circ} \mathrm{C}$; Heating rate of calcinations: $5^{\circ} \mathrm{C} / \mathrm{min}$; Calcinations time: $1.5 \mathrm{~h}$.

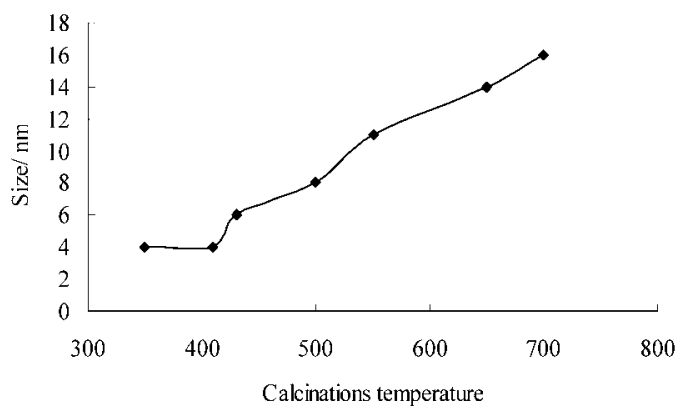

Figure 6. Effect of calcinations temperature on the size. Conditions: Titration rate of $\mathrm{NaOH}: 0.25 \mathrm{~mL} / \mathrm{min}$; Ultrasonic time: $20 \mathrm{~min}$; $\mathrm{NaOH}$ concentration: 0.48 $\mathrm{mol} / \mathrm{L}$; Ultrasonic power: $250 \mathrm{~W}$; Heating rate of calcinations: $5{ }^{\circ} \mathrm{C} / \mathrm{min}$; Calcinations time: $1.5 \mathrm{~h}$.

decomposed. Different size crystal has different vapour pressure. Vapour pressure of small size crystal is high. And vapour pressure of big size crystal is low. So the process that small size crystal turn into big size crystal will happen automatically. The process (small size crystal is disappeared and big size crystal grow bigger than before) proceeds very quickly, especially at high temperature. With the calcinations time being prolonged, the process will be achieved completely. Because the crystal exists for a long time at high calcinations temperature, the crystal size is easy to become bigger. Thus, nano-particles with big size and wide size distribution can be gotten. For the same reason, although the intermediate can be completely decomposed quickly at high calcinations temperature, nano-particle with big size is easy to be obtained due to aggregation. So, in order to get nano-particle having small size and high surface area, calcinations temperature should not be too high and calcinations time should not be too long.

Effect of calcinations temperature and calcinations time on the size was presented in Fig. 6 and Fig. 7. From Fig. 6, we could know the size of nano-MgO was increased with the increase of calcinations temperature. For nano- $\mathrm{MgO}$, the smallest size was $4 \mathrm{~nm}$. The size was increased to about 16 $\mathrm{nm}$ when calcinations temperature was increased to $700{ }^{\circ} \mathrm{C}$. From Fig. 7, with increase of calcinations time (more than $1.5 \mathrm{~h}$ ), the size of nano- $\mathrm{MgO}$ was increased too. When calcinations time reached $3.0 \mathrm{~h}$, the size was about $18 \mathrm{~nm}$. When calcinations time was below $1.5 \mathrm{~h}$, nano- $\mathrm{MgO}$ with big size could be obtained. The reason might be the inter- 
mediate was not decomposed completely. Thus, through controlling calcinations temperature and calcinations time, nano- $\mathrm{MgO}$ with different sizes could be obtained. In order to get smaller size particles, Calcinations temperature was about $410{ }^{\circ} \mathrm{C}$ and calcinations time was $1.5 \mathrm{~h}$.

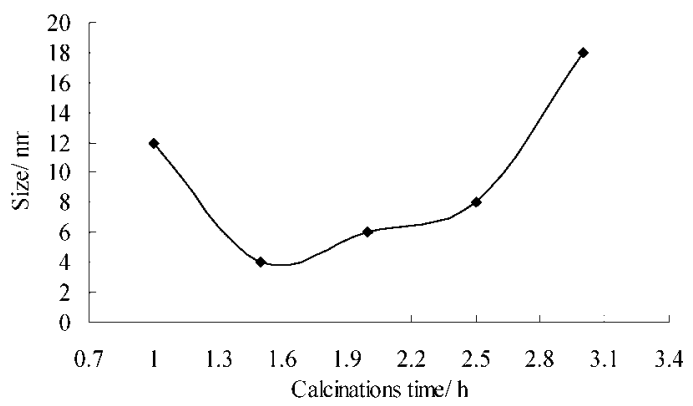

Figure 7. Effect of calcinations time on the size. Conditions: Titration rate of $\mathrm{NaOH}: 0.25 \mathrm{~mL} / \mathrm{min}$; Ultrasonic time: $20 \mathrm{~min}$; $\mathrm{NaOH}$ concentration: 048 mol/L; Ultrasonic power: $250 \mathrm{~W}$; Calcinations temperature: $410{ }^{\circ} \mathrm{C}$; Heating rate of calcinations: $5{ }^{\circ} \mathrm{C} / \mathrm{min}$.

Effect of heating rate of calcinations on the size Heating rate of calcinations can affect nanoparticle size. When heating rate of calcinations is very fast, big size nano-MgO aggregation is easy to be gotten due to urgent collapse of the intermediate. When heating rate of calcinations is low, nano$\mathrm{MgO}$ may exist for a long time at high calcinations temperature. What's more, it will decrease production efficiency. So, optimized heating rate of calcinations must exist. Effect of heating rate of calcinations on the size of nano-MgO was presented in Fig.

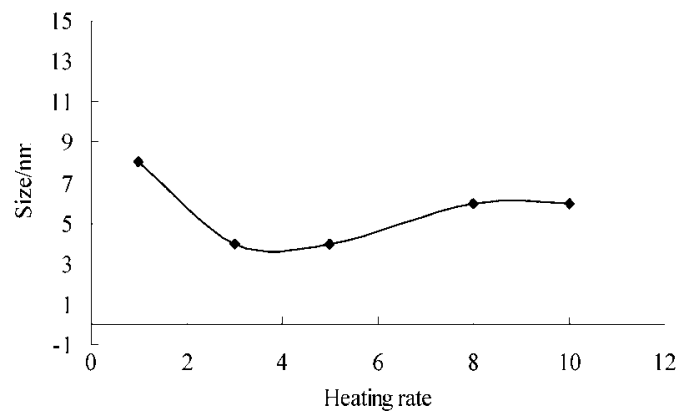

Figure 8. Effect of heating rate of calcinations on the size. Conditions: Titration rate of $\mathrm{NaOH}$ : 0.25 $\mathrm{mL} / \mathrm{min}$; Ultrasonic time: $20 \mathrm{~min}$; $\mathrm{NaOH}$ concentration: $0.48 \mathrm{~mol} / \mathrm{L}$; Ultrasonic power: $250 \mathrm{~W}$; Calcinations temperature: $410{ }^{\circ} \mathrm{C}$.
8. From Fig. 8, we could know that heating rate of calcinations had little effect on the size. With the increased heating rate, the size of nano- $\mathrm{MgO}$ was decreased. When heating rate was in the range of 5$10{ }^{\circ} \mathrm{C} / \mathrm{min}$, the size nearly did not change. Thus, Optimized heating rate was $5-10^{\circ} \mathrm{C} / \mathrm{min}$.

The sizes distribution was presented in Fig.9. From Fig.9, the sizes distribution was narrow. Nano- $\mathrm{MgO}$ size was between $12 \mathrm{~nm}$ and $18 \mathrm{~nm}$. The distribution was consistent with XRD result.

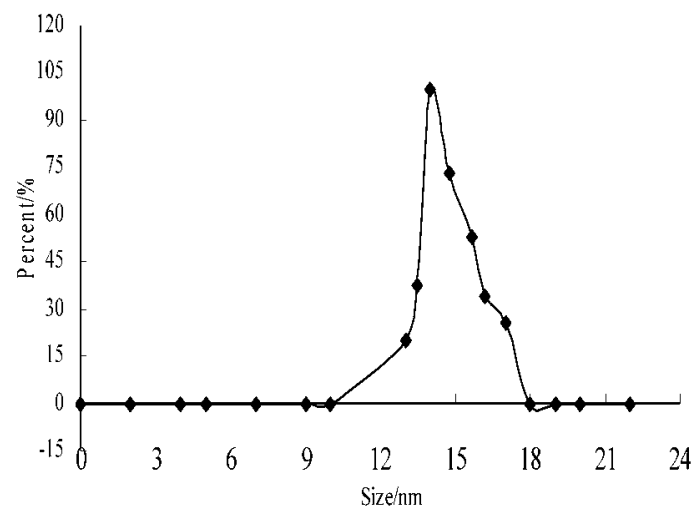

Figure 9. The sizes distribution of $\mathrm{MgO}$ nano-particles. Nano-particles were obtained at calcinations temperature $650{ }^{\circ} \mathrm{C}$, calcinations time $1.5 \mathrm{~h}$, heating rate $5{ }^{\circ} \mathrm{C} / \mathrm{min}$.

Structural and Morphologies characterizations of nano- $\mathrm{MgO}$

TEM of $\mathrm{MgO}$ nano-particles were illustrated in Fig.10. From Fig.10, MgO nano-particles could be dispersed very well in ethanol. Few aggregate could be found. $\mathrm{MgO}$ powder appeared with an

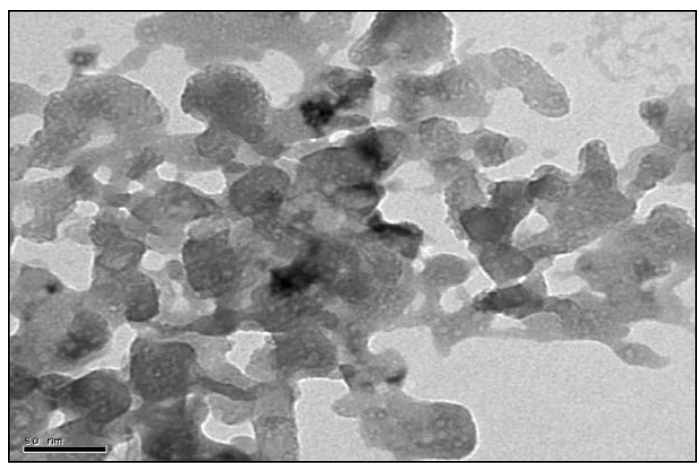

Figure 10. TEM of nano-MgO. Nano-particles were obtained at calcinations temperature $650{ }^{\circ} \mathrm{C}$, calcinations time $1.5 \mathrm{~h}$, heating rate $5{ }^{\circ} \mathrm{C} / \mathrm{min}$. 


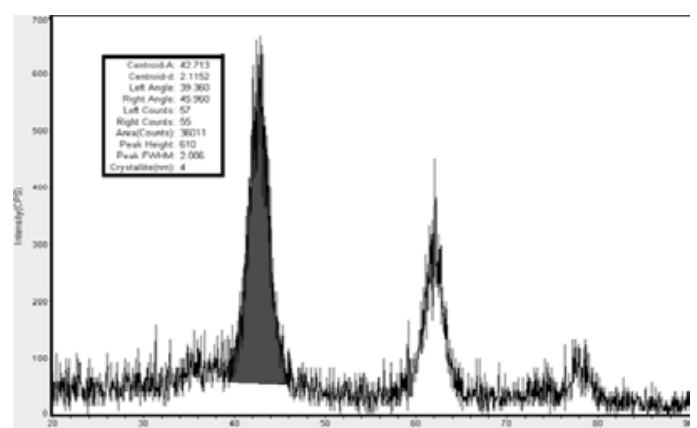

Figure 11. $\mathrm{XRD}$ of nano-MgO. Nano-particles were obtained at calcinations temperature $410{ }^{\circ} \mathrm{C}$, calcinations time $1.5 \mathrm{~h}$, heating rate $5^{\circ} \mathrm{C} / \mathrm{min}$.

average particle size about $14 \mathrm{~nm}$. The result matched with the particle sizes distribution. The particles were regular and spherical in shape.

The structure of nano-MgO was first characterized by XRD (Fig.11). All peaks were consistent with the peaks of standard MgO. XRD patterns of Fig.11 showed broadening of the peaks indicative of the ultra fine nature of the crystallite. The crystallite size calculated using Scherrer's formula was about $4 \mathrm{~nm}$. No peaks from any other phases of $\mathrm{MgO}$ were observed.

\section{Conclusions}

$\mathrm{MgO}$ nano-particles were prepared by sonication method using $\mathrm{Mg}\left(\mathrm{CH}_{3} \mathrm{COO}\right)_{2} \cdot 2 \mathrm{H}_{2} \mathrm{O}$ as precursor, $\mathrm{NaOH}$ aqueous solution as precipitant. Through experiments research, the size of nano- $\mathrm{MgO}$ about $4 \mathrm{~nm}$ could be obtained under the following conditions (ultrasonic time $20 \mathrm{~min}$, ultrasonic power $250 \mathrm{~W}$, titration rate of $\mathrm{NaOH}$ $0.25 \mathrm{~mL} / \mathrm{min}, \mathrm{NaOH}$ concentration $0.48 \mathrm{~mol} / \mathrm{L}$, calcinations temperature $410^{\circ} \mathrm{C}$, calcination time $1.5 \mathrm{~h}$, heating rate of calcination $5{ }^{\circ} \mathrm{C} / \mathrm{min}$ ). It was simple and effective method to prepare $\mathrm{MgO}$ nano-particles.

Received 18 July 2007

Accepted 25 September 2007

\section{References}

[1] R.W. Kelsall, I.W. Hamley, M. Geoghegan, Nanoscale Science and Technology, John Wiley and Sons Inc., 2005
[2] M. Di Ventra, Introduction to Nanoscale Science and Technology, Springer, 2004

[3] L. Tosheva, V.P. Valtchev, Chem. Mater. 17 (2005) 2494

[4] E. Manova, T. Tsoncheva, D. Paneva, I. Mitov, K. Tenchev, L. Petrov, Appl. Catal. A: Gen 277 (2004) 119

[5] Mao-Sung Wu, Pin-Chi J. Chiang, Jyh-Tsung Lee, JungCheng Lin, J. Phys. Chem. B 109 (2005) 23279

[6] L. Carbone, S. Kudera, E. Carlino, W.J. Parak, C. Giannini, R. Cingolani, L. Manna, J. Am. Chem. Soc. 128 (2006) 748

[7] M. Regragui, M. Addou, A. Outzourhit, J.C. Bernede, E.E. Idrissi, E. Benseddik, A. Kachouane, Thin Solid Films 358 (2000) 40

[8] J. Xie, X. Cao, J. Li, H. Zhan, Y. Xia, Y. Zhou, Ultrason. Sonochem. 12 (2005) 289

[9] E. Shen, C. Wang, E. Wang, Z. Kang, L. Gao, C. Hu, L. Xu, Mater. Lett. 58 (2004) 3761

[10] Kh. Ghanbari, M.F. Mousavi, M. Shamsipur, Electrochim. Acta 52 (2006) 1514.

[11] S.F. Wang, F. Gu, M.K. Lu“ , Langmuir 22 (2006) 398

[12] Jin-Zhong Xu, Shu Xu, Jun Geng, Gen-Xi Li, Jun-Jie Zhu, Ultrason. Sonochem. 13 (2006) 451

[13] Sheng-Yi Zhang, Y. Liu, X. Ma, Hong-Yuan Chen, J. Phys. Chem. B 110 (2006) 9041

[14] H. Lei, Y.-J. Tang, J.-J. Wei, J. Li, X.-B. Li, H.-L. Shi, Ultrason. Sonochem. 14 (2007) 81

[15] V.G. Kumar, K.B. Kim, Ultrason. Sonochem. 13 (2006) 549

[16] Chang-Jie Mao, Hong-Cheng Pan, Xing-Cai Wu, Jun-Jie

Zhu, Hong- Yuan Chen, J. Phys. Chem. B 110 (2006) 14709

[17] K.S. Suslick, M. Fang, T. Hyeon, J. Am. Chem. Soc. 118 (1996) 11960

[18] H. Zhou, Z. Zhou, Solid State Ionics 176 (2005) 1909

[19] Q.S. Song, Y.Y. Li, S.L.I. Chan, J. Appl. Electrochem. 35 (2005) 157

[20] J. Zhu, Z. Lu, S.T. Aruna, D. Aurbach, A. Gedanken, Chem. Mater. 12 (2000) 2557

[21] J.C. Yu, J. Yu, L. Zhang, W. Ho, J. Photochem. Photobiol. A: Chem. 148 (2002) 263

[22] L. Jiang, G. Sun, Z. Zhou, S. Sun, Q. Wang, S. Yan, H. Li, J. Tian, J. Guo, B. Zhou, Q. Xin, J. Phys. Chem. B 109 (2005) 8774

[23] S.H. Liang, I.D. Gay, J. Catal. 1986, 101, 293

[24] H. Tsuji, F. Yagi, H. Hattori, H. Kita, J. Catal. 1994, 148, 759

[25] Alvarado E, Martinez L M T, Fuentes A F, et al. Polyhedron, 2000, 19, 2345-2351

[26] Ardizzone S, Bianchi C L, Vercelli B. Colloid Surf A, 1998, 144: 9-17

[27] Wu Shan, Zheng Xingfang, Chen Jinxin, et al. Acta Scientiarum Naturalium Universitatis Nankaiensis, 2004, 37 : 73-77

[28] S. Y. Zhang, S. W. Ding, S. J. Liu, et al. Chin. Acta Chimica Sinca, 2002, 60(7): 1225-1229

[29] K.S. Suslick, G. Price, J. Annu. Rev. Mater. Sci. 29 (1999) 295.

[30] N. Wang, B. Q. Li, Chin. Chem. Bull, 1999, 62(3): 2632

[31] X. Y. Liang, Z. Ma, Z.C. Bai, et al. Chin. Acta. Physico Chimica Sinia, 2002, 18(6): 567-571

[32] W. L. Guo, X. K. Wang, Z. M. Lin, et al. Chem. J. Chinese Univerities, 2002, 23(8):1592-1594

[33] J. J. Zhu, Z. H. Lu, S.T. Aruna. Chem. Mater, 2000, 12: 2557-2566

[34] H. Kroeber, U. Teipel. Int. Annu. Conf. ICT, Germany, Fraunhofer, 1998, 29 $9^{\text {th }}, 171$ 